\title{
Aboveground Biomass Carbon in the Alpine and Arctic Treeline Ecotones in the Ural Region
}

\author{
Vladimir A. Usoltsev ${ }^{1,2}$, Zoltan Somogyi ${ }^{3}$, Viktor P. Chasovskikh ${ }^{2} \&$ Yuliya V. Noritsina ${ }^{1}$ \\ ${ }^{1}$ Botanical Garden of the Ural Branch of the Russian Academy of Sciences, Yekaterinburg, Russia \\ ${ }^{2}$ Ural State Forest Engineering University, Yekaterinburg, Russia \\ ${ }^{3}$ Hungarian Forest Research Institute, Budapest, Hungary \\ Correspondence: Vladimir A. Usoltsev, Botanical Garden of the Ural Branch of the Russian Academy of \\ Sciences, Russia. Tel: 7-343-254-6159. E-mail: usoltsev50@mail.ru
}

Received: August 3, 2014 Accepted: August 15, 2014 Online Published: August 20, 2014

doi:10.5539/enrr.v4n4p1 URL: http://dx.doi.org/10.5539/enrr.v4n4p1

\begin{abstract}
This paper reports on measured carbon stocks in the forests of two treeline ecotones of the Ural region where climate change might improve growing conditions. The first is an alpine ecotone that is represented by an altitudinal gradient of the spruce-dominated forests on the Western slope of the Tylaiskii Kamen Mountain (Western part of the Konzhakovskii-Tylaiskii-Serebryanskii Mountain system, $59^{\circ} 30^{\prime} \mathrm{N}, 59^{0} 00^{\prime} \mathrm{E}$ ), at the alpine timber line that has risen from 864 to $960 \mathrm{~m}$ above sea level in the course of the last 100 years. The second is an arctic ecotone in larch-dominated forests at the lower course of the Pur River $\left(67^{0} \mathrm{~N}, 78^{0} \mathrm{E}\right)$, at the transition zone between closed floodplain forests and open or island-like communities of upland forests on tundra permafrost. According to our results, there are large differences in the carbon of the aboveground biomass of both ecotones across environmental gradients. In the alpine treeline ecotone, a 19-fold drop of the carbon stocks was detected between the lower and higher altitudinal levels. In the arctic ecotone the aboveground biomass carbon stock of forests of similar densities (1300 to 1700 trees per ha) was 7 times as much in the river flood bed, and 5 times as much in mature, dense forests as the low density forests at higher elevations.
\end{abstract}

Keywords: treeline, ecotone, carbon stock, Tylaiskii Kamen Mountain, the lower Pur River

\section{Introduction}

Advancing climate change and international agreements of the last decades (United Nations Framework Convention on Climate Change, the Kyoto Protocol, etc.) have been the driving force behind the study of ecosystem response to global and regional climate change. The study of spatiotemporal dynamics of the biological productivity of plant transitional communities in the highlands and on the Northern and Southern zonal boundaries of forest vegetation is extremely important because of their huge area (the area of near tundra forests of Russia is about 44 million hectares, Karelin et al., 1995). This forest vegetation plays a significant role in the global forest carbon cycle (Medvedev, 1952; Norin, 1961; Tikhomirov, 1962; Buks, 1966; Famelis, 1977; Shiyatov, 1985; Kullman, 1990; Stevens \& Fox, 1991; Hessl, Baker, 1997; Kharuk et al., 1998; Körner, 1999; Bugmann, Pfister, 2000; Camarero et al., 2000; Holtmeier, 2003; Shiyatov, 2003; Shiyatov et al., 2005, 2007; Kapralov et al., 2006; Juntunen, Neuvonen, 2006; Fomin, 2009; Grafius, 2012).

The estimation of the changes of climatic factors and their influence on the formation and growth of the forest stands in transition zones should also be increasingly pursued because intensive vegetation response to climate change can be expected, and is indeed observed, right in these zones. Several studies have already demonstrated the ecological and global role of these forests, and the shift of the forest boundaries Northwards (in the arctic) and upwards (on mountains) under the influence of climatic warming (Gorchakovskii \& Shiyatov, 1985; Grigoriev et al., 2012; IPCC, 2013). However, the production indices of these forests are the least explored on the arctic and alpine limits of forests, and this study attempts to fill relevant gaps in this regard.

The first descriptions of the shift of vegetation at its upper limit in the mountains of Europe emerged more than 200 years ago (Hacquet, 1780). More recently, the devastating impact of snow avalanches, especially in the mid-1950s in the Alps, became a very significant incentive for forest research at the upper vegetation limit (Holtmeier, 2003). 
H. Walter and E. Box (1976) have introduced the concept of zonal ecotone as a transition belt from forest to non-forest (tundra, steppe, swamp, etc.) vegetation, occurring under the influence of natural factors.

Under boreal conditions, the effect of abiotic factors is most evident in alpine ecotones where such effects on the changes in productivity and the structure of plant communities are concentrated on a much smaller area along the altitudinal gradient than in the lowland habitats along the artic gradient.

In the boreal zone the alpine ecotones belong to the category of "cold treelines" (Stevens \& Fox, 1991). When climbing upwards, forest productivity declines due to lack of heat. This general pattern is characterized by different quantitative characteristics in different regions of the boreal zone. For example, in the middle taiga subzone of the Northern Ural Mountains while climbing the slope of the Denezhkin Kamen Mountain from 740 to $840 \mathrm{~m}$ a.s.l., the tree height of Picea obovata forests drops from 8 to $1 \mathrm{~m}$ (Krylova \& Leskov, 1959). In the Subpolar Urals, while climbing on the North-East slope of the Khus'-Oika Mountain from 600 to $700 \mathrm{~m}$ a.s.l., the aboveground biomass of Larix sibirica forests drops from 40.7 to $0.17 \mathrm{t} \cdot \mathrm{ha}^{-1}$, whereas their age drops from 90 to 48 years (Grigoriev et al., 2012).

In the Northern part of Central Siberia on the Putorana Plateau, with the rise from a river valley ( $170 \mathrm{~m}$ a.s.l.) up to the border with the alpine tundra (390 m a.s.l.), the aboveground biomass of Larix sibirica forests decreases from 40.6 to $8.6 \mathrm{t} \cdot \mathrm{ha}^{-1}$ (Kirdyanov et al., 2006). In mixed coniferous-deciduous forests of the Far East, while climbing the slope of the Southern Sikhote-Alin' Mountain from 550 to $840 \mathrm{~m}$ a.s.1., the tree height of Picea ajanensis forests drops from 32 to $22 \mathrm{~m}$, whereas the mean diameter drops from 26 to $16 \mathrm{~cm}$ and stem volume from 360 to $160 \mathrm{~m}^{3} \cdot \mathrm{ha}^{-1}$ (Doyev, 1973).

Concerning the arctic ecotones, the polar boundary of woody vegetation in Eurasia is divided into five sections, each of which is formed by a single wood species (Figure 1). Against a background of low heat availability and permafrost development in soils, one section is represented by Larix sibirica that generates two types of communities: open woodlands on mountain-tundra of the Polar Urals, and floodplain forests as well as tundra woodland on the West Siberian Plain correspondingly. Due to both shore drainage and heat sink alongside with sediment discharge (Mironov, Agafonov, 1992), floodplain larch forests in the circumpolar area do not differ from similar forest stand in the taiga zone. Larch under these conditions develops best in the valley of the Hadytayakha River which is a tributary of the Pur River, where it has the look of a tall (up to $25 \mathrm{~m}$ ) tree with narrow cylindrical crown (Matveev, Semerikov, 1993). In contrast, the upland larch forests represent low-productive sparse communities on permafrost with thin soil horizon. The ground water flow over permafrost habitats of the upland forests is normally negligible (Pozdnyakov, 1963). In the lowland tundra open woodlands, larch is a low (4-9 m) tree, often with curved trunk and low down crown. Therefore, the stem volume of riparian larch forests reaches $196 \pm 6 \mathrm{~m}^{3}$ per ha, whereas only $64 \pm 34 \mathrm{~m}^{3}$ per ha in watersheds (in upland forests) (Pryazhnikov \& Utkin, 1998).

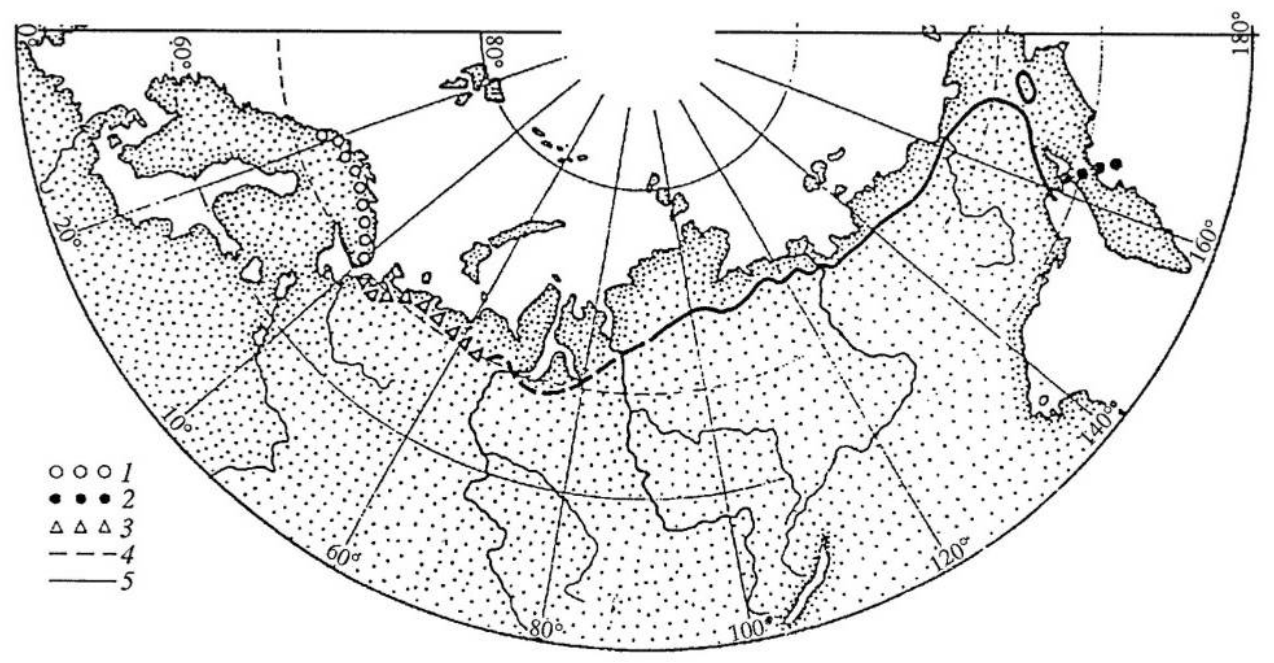

Figure 1. The Southern boundary of the Arctic zone of woody vegetation in Eurasia. The boundary is formed by: Betula tortuosa Ldb. (1); B. ermani Cham. (2); Picea obovata Ldb. (3); Larix sibirica Ldb. (4); and L. gmelinii and L. cajanderi (5) (Tikhomirov, 1962) 
With regard to the spatial distribution of the boreal alpine and artic forests, remarkable changes due to climate change have been observed. The borderline of closed mountain Picea obovata forests is reported to have advanced up to $60 \mathrm{~m}$ higher than it was 49 years earlier in the North Urals and up to $60-80 \mathrm{~m}$ higher than it was 70 years earlier in the South Urals, whereas the borderline of Larix sibirica forests moved by $20-40 \mathrm{~m}$ higher than 40 years earlier in the Polar Urals because of climate warming (Moiseev \& Shiyatov, 2003; Kapralov et al., 2006). The limit between the Larix gmelinii forests in the lowland of the Taymyr Peninsula $\left(72^{0} 28^{\prime} \mathrm{N}\right)$ and the tundra advanced northwards at the rate of about $2 \mathrm{~m}$ annually (Kharuk et al., 1998) between 1965 and 1991.

In this paper, we report the first data on forest biomass carbon stocks in an alpine altitudinal gradient and an arctic ecotone.

\section{Study Areas}

The study areas can be found in the unmanaged forests of the Ural region (Figure 2). The study area in the altitudinal treeline ecotone was established on the Western slope of the Tylaiskii Kamen Mountain (Western part of the Konzhakovskii-Tylaiskii-Serebryanskii Mountain System, $59^{0} 30^{\prime} \mathrm{N}, 59^{0} 00^{\prime}$ E), i.e. on the belt of the upper tree limit. This limit has risen from 864 to $960 \mathrm{~m}$ a.s.l. for the last 100 years (Figure 3). It is in this zone where open low tree Picea woodlands reach the upper forest limit with a canopy density ranging from $30 \%$ to $90 \%$. The extension of the treeline forests is dominated by Picea that reaches $19 \%$ of the common treeline of the Tylaiskii Kamen Mountain.

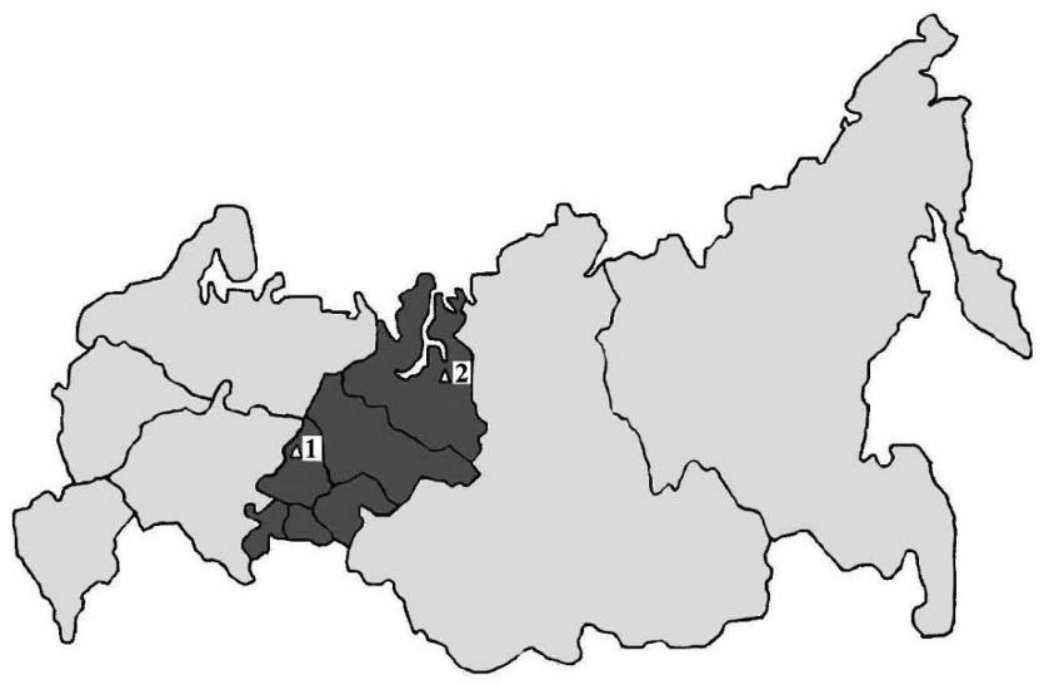

Figure 2. Sample plot locations in the Ural region: (1) in the altitudinal treeline alpine forest-tundra ecotone in the Konzhakovski Kamen Mountains and (2) in the arctic zonal ecotone in the lower Pur River 


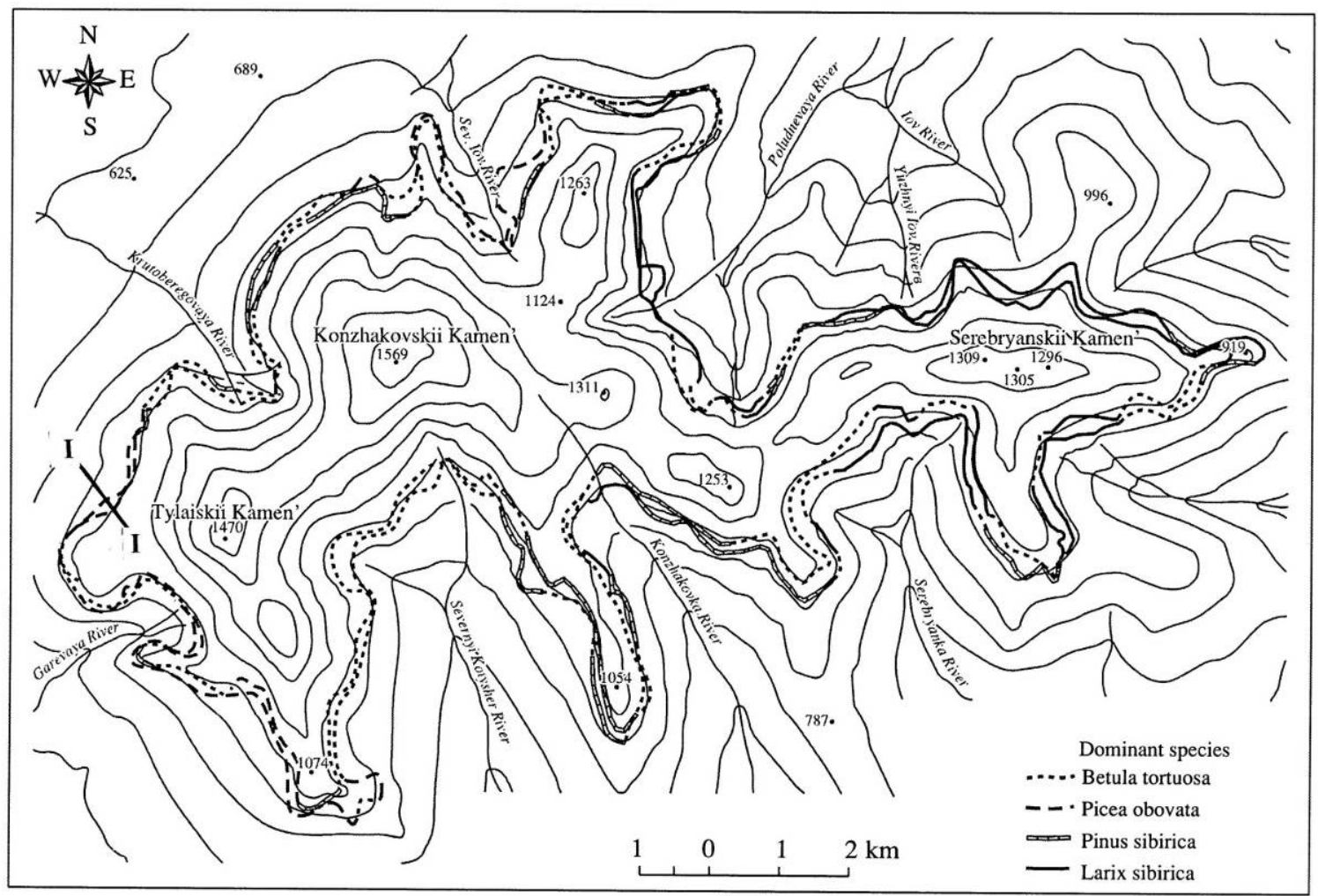

Figure 3. The location of the profile transect (I-I, far left of the map) of the sample plots on the western slope of the Tylaiskii Kamen' Mountain (which is the Western part of the Konzhakovskii-Tylaiskii-Serebryanskii Mountain System, $59^{0} 03^{\prime} \mathrm{N}, 59^{0} 00^{\prime} \mathrm{E}$ ). The map was designed by Kapralov et al. (2006) and denotes the position of the upper low-forest boundary in 1956 (lower line) and 2005 (upper line) with regard to dominance of different tree species

Climate conditions in the area studied are cool, excessively humid and are characterized by short and moderately warm summers, long and cold winters and snow cover formation already at the end of September. The average annual air temperature is $1.4{ }^{\circ} \mathrm{C}$, the annual rainfall is up to $1200 \mathrm{~mm}$, and the mean relative air humidity is $74 \%$. The maximum snow depth in the intermountain depressions is $86 \mathrm{~cm}$ for open areas and $103 \mathrm{~cm}$ for forested areas. When climbing the mountains, snow depth increases by 17 or $18 \mathrm{~cm}$ every $100 \mathrm{~m}$.

The studies were carried out at three places along a transect (Figure 3) at high-altitude levels - upper, middle and lower, at the altitude of 960, 924 and $864 \mathrm{~m}$ a.s.l. respectively (Figures 4-6).

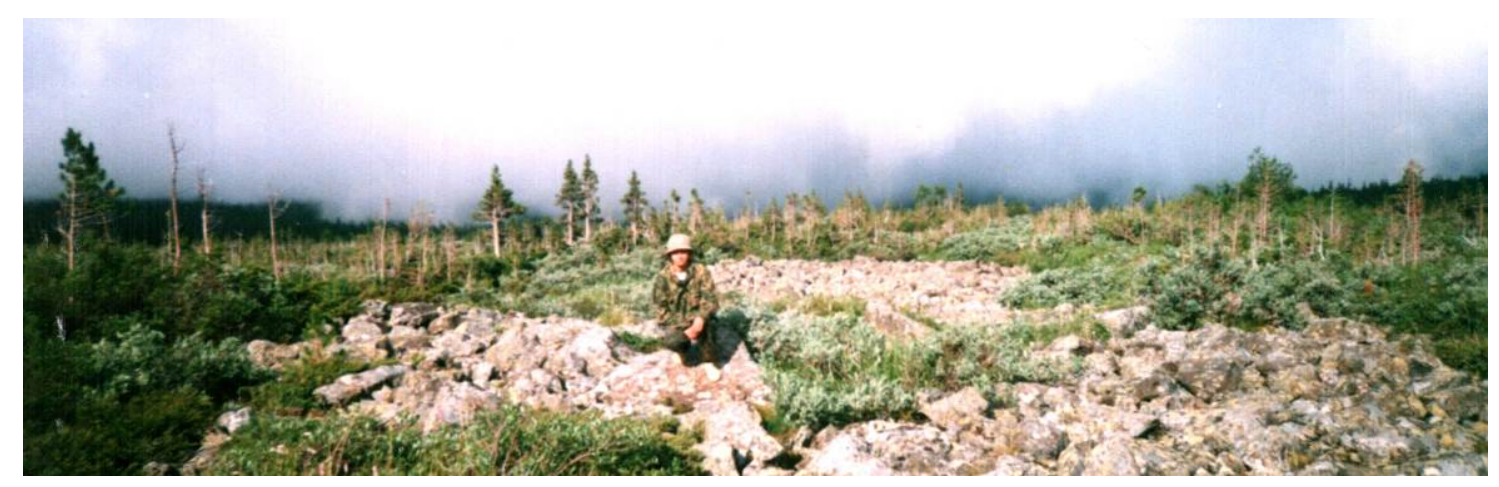

Figure 4. The forest of the sample plot at the upper high-altitude level (960 $\mathrm{m}$ a.s.l.) 


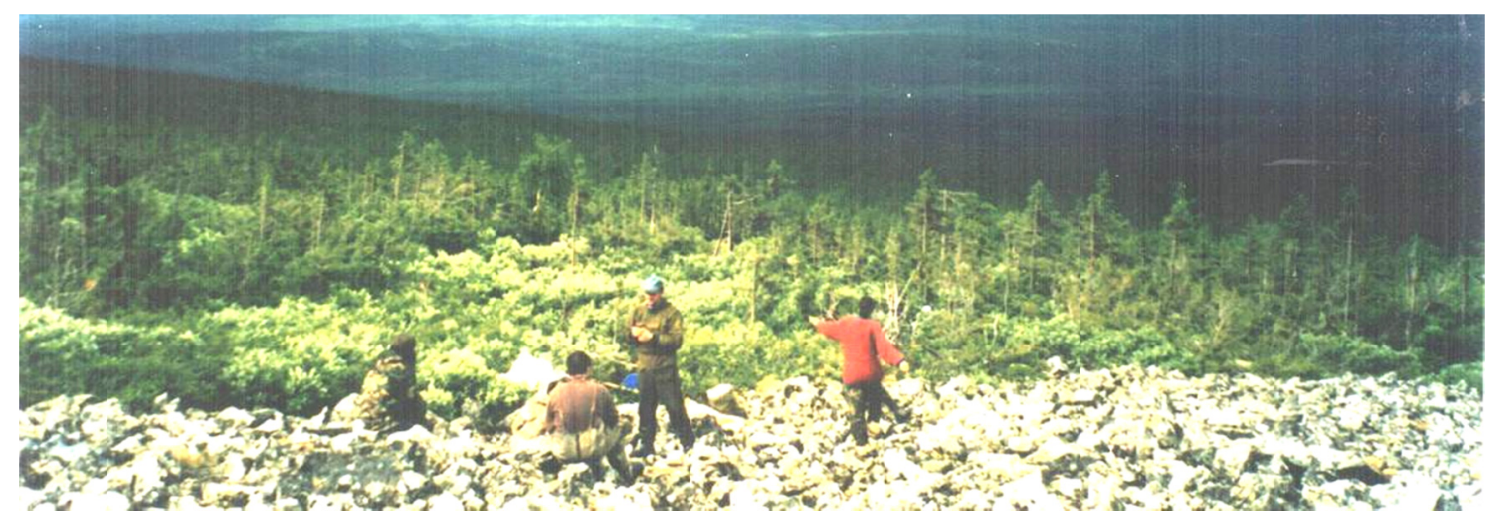

Figure 5. The forest of the sample plot at the middle high-altitude level (924 m a.s.1.)

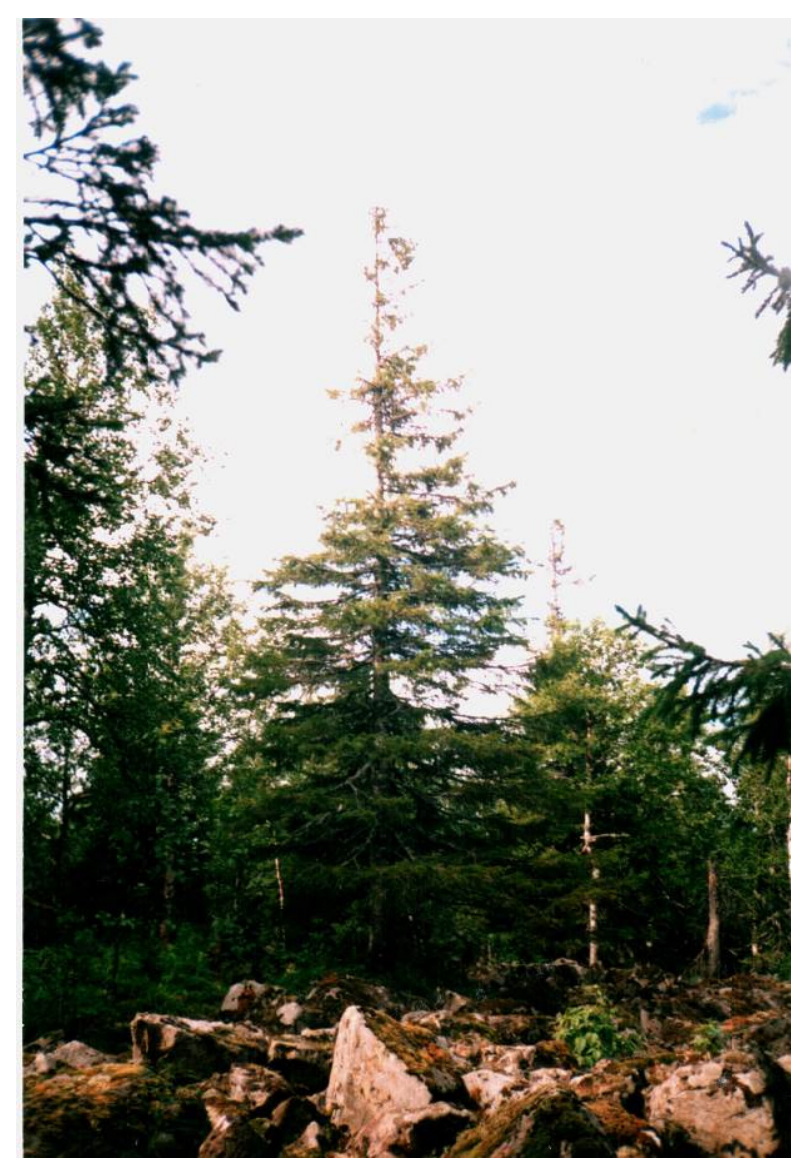

Figure 6. The forest of the sample plot at the lower high-altitude level (864 $\mathrm{m}$ a.s.1.)

The study area in the arctic ecotone was established in the the basin of the Hadytoyakha River, which is a tributary of the lower Pur River, approximately at the latitude of the Arctic Circle $\left(66^{\circ} 30^{\prime} \mathrm{N}\right.$ and $\left.78^{\circ} 00^{\prime} \mathrm{E}\right)$, both on floodplain terraces (Figure 7) and uplands (Figure 8). In this region, closed larch forests with relatively high productivity stretch along flood beds almost to the river mouth and appear up to Samburg settlement, reaching the Northern limit of the forest-tundra. Larch forests in this region represent $33 \%$ of the total forest area.. The research area is located approximately $70 \mathrm{~km}$ north of the Urengoy settlement (Figure 9). 

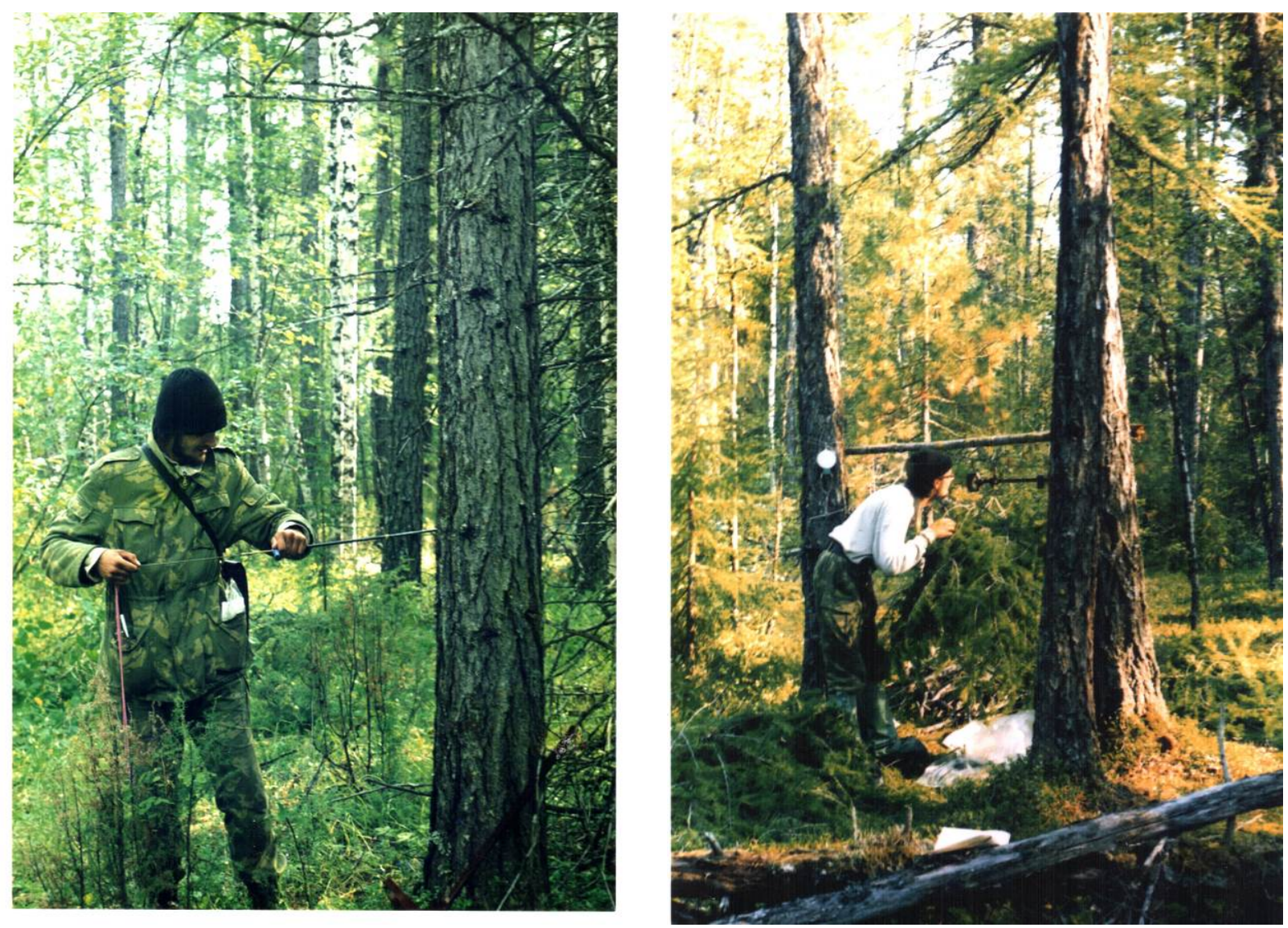

Figure 7. Sample plot No. 17 in the 350 year-old Larch forest of Ledosum type on floodplain terraces (left), and biomass measurement at the same plot (right)

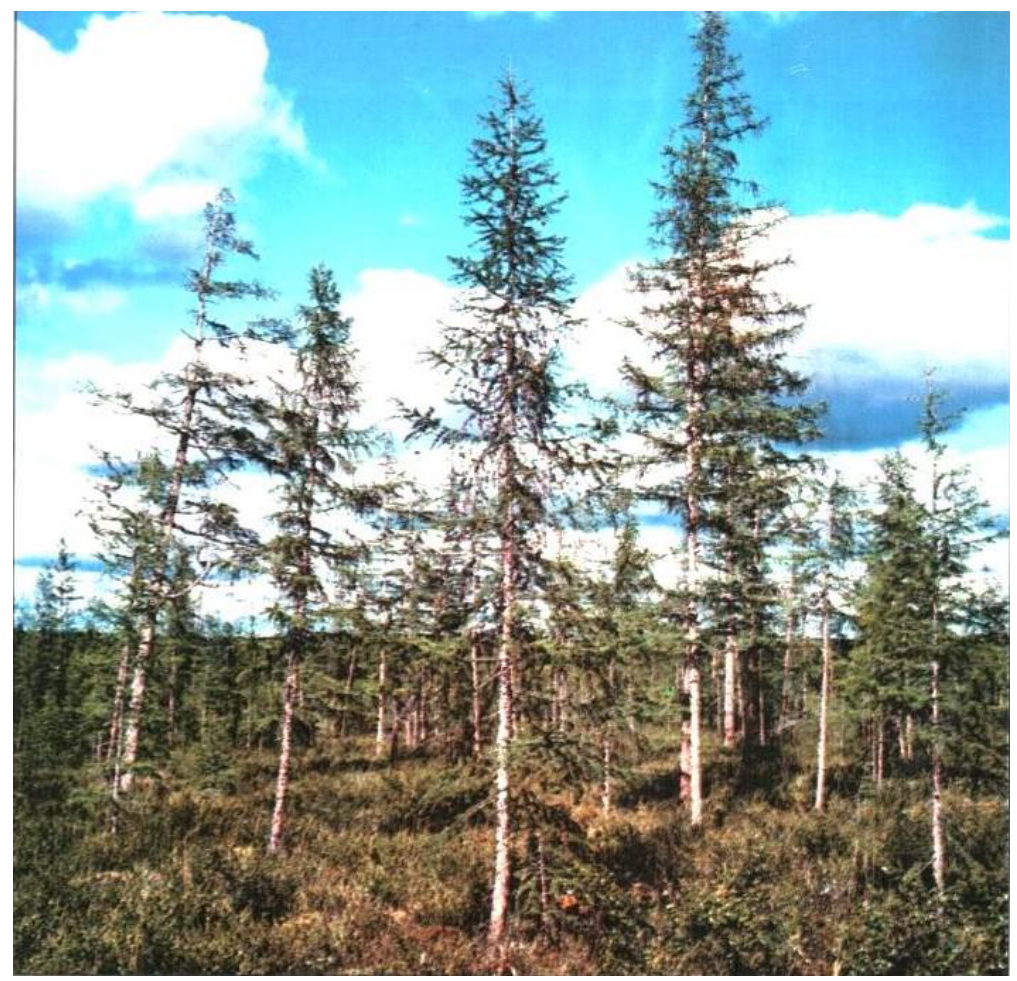

Figure 8. Larch forest of Vacciniosum type on the sample plot No 2 in the age of 102 years on uplands 


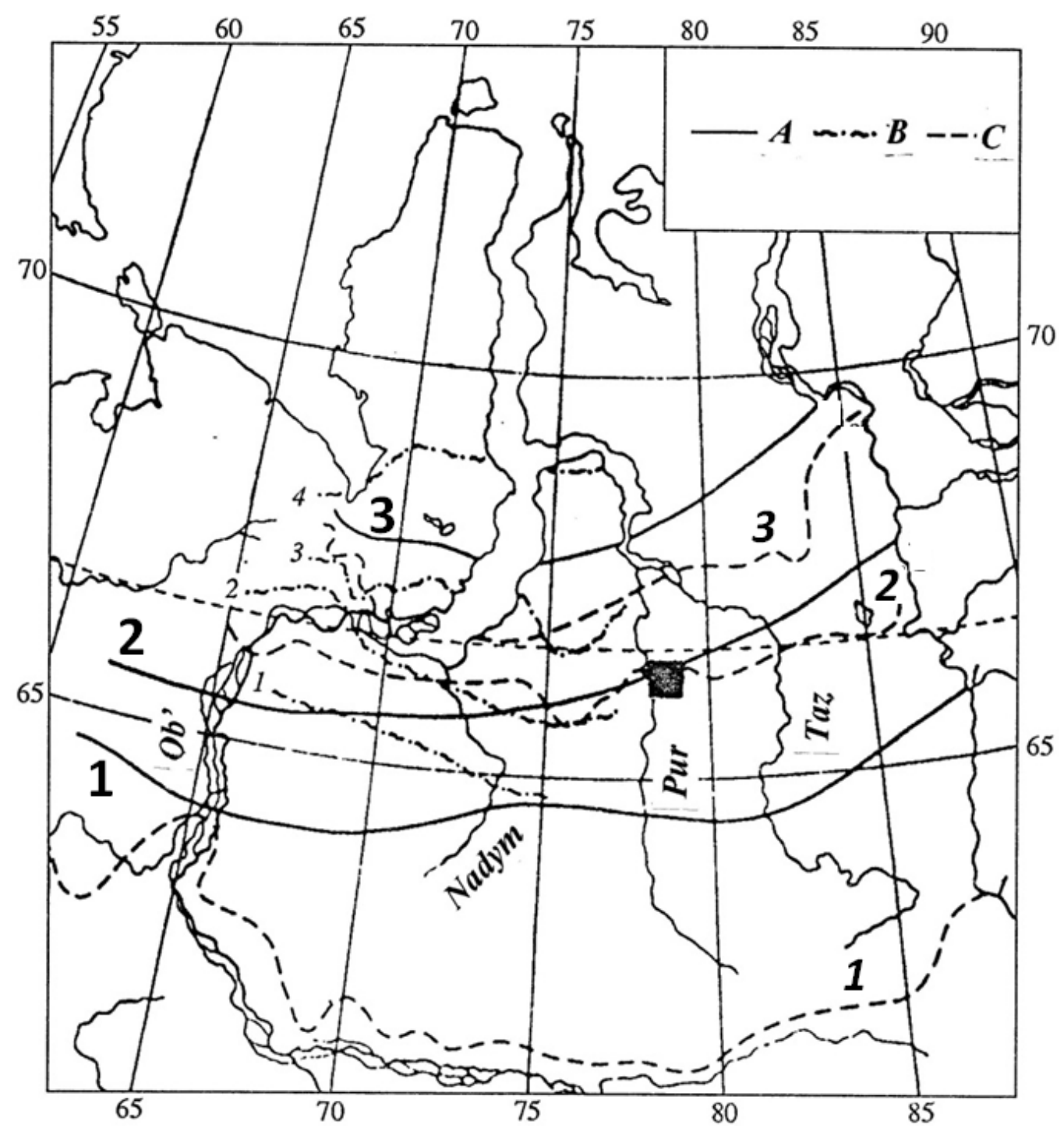

Figure 9. Zonal division of the plant cover in the circumpolar region of Western Siberia according to different authors (Norin, 1961): A, large numbers on the left: 1-2 - Northern taiga, 2-3 - forest-tundra (Gorodkov, 1916); B, small numbers on the left: 1-2 - Southern forest-tundra, 2-3 - Northern forest-tundra, 3-4 - Southern tundra (Andreyev, 1938); C, letters on the right: 1-2 - Northern taiga, 2-3 - tundra low-forest (Sochava et al., 1953). The square around the middle designates the place of the research area

\section{Methods}

The alpine ecotone was studied in three 20x20 m plots that were established from July to August. Standard forest mensuration data of the sample plots are given in Table 1.

The study in the arctic ecotone was carried out on 4 sample plots in the watersheds (Vacciniosum type) and 13 plots in the flood lands (Hylocomiosum and Ledosum types) larch forests. The size of the plots at higher elevations varied from 0.10 to 0.48 hectares, depending on age, which varied between 45 and 100 years. At a distance of about $3 \mathrm{~km}$ from the river, at sample plot No. 1, the typical vegetation is formed by larch, both as single trees and in small communities. Sample plots No. 2 to 4 were established in three relatively large spots at a distance of 50 to $100 \mathrm{~m}$ from the water line in an area of typically sparse spots and stands of larch on permafrost that approaches directly the top terrace of the floodplain with an abrupt bank. The floodplain plots No. 5 to 17 (sized from 0.14 to 0.41 hectares) were established along a river bank at a distance of 20 to $50 \mathrm{~m}$ from the water line. When moving away from the floodplain, small islands of birch and coniferous-deciduous forests appear at higher elevations, whereas willow scrubs can be seen along small streams and oxbows. The standard forest mensuration data of the sample plots are given in Table 2. 
Table 1. Standard forest mensuration data of the sample plots in the alpine ecotone*

\begin{tabular}{|c|c|c|c|c|c|c|}
\hline Tree species & $A$, years & $H, \mathrm{~m}$ & $D, \mathrm{~cm}$ & $G, \mathrm{~m}^{2} \mathrm{ha}^{-1}$ & $N$, trees ha ${ }^{-1}$ & $V, \mathrm{~m}^{5} \mathrm{ha}^{-1}$ \\
\hline \multicolumn{7}{|c|}{ Plot 1: altitudinal level 1 (960 $\mathrm{m}$ a.s.l.) } \\
\hline Picea obovata & 28 & 1.65 & 2.66 & 0.96 & 1725 & 2.94 \\
\hline Pinus sibirica & 40 & 1.09 & 2.12 & 0.05 & 142 & 0.17 \\
\hline Total & 30 & 1.62 & 2.62 & 1.01 & 1867 & 3.11 \\
\hline \multicolumn{7}{|c|}{ Plot 2: altitudinal level 2 (924 m a.s.l.) } \\
\hline Picea obovata & 79 & 2.94 & 6.94 & 3.85 & 1017 & 18.9 \\
\hline Abies sibirica & 102 & 2.02 & 3.38 & 0.36 & 400 & 2.02 \\
\hline Betula alba & 40 & 5.62 & 12.7 & 0.32 & 25 & 1.29 \\
\hline Total & 80 & 3.13 & 6.32 & 4.53 & 1442 & 22.2 \\
\hline \multicolumn{7}{|c|}{ Plot 3: altitudinal level 3 (864 $m$ a.s.l.) } \\
\hline Picea obovata & 99 & 5.56 & 14.8 & 10.4 & 608 & 37.6 \\
\hline Abies sibirica & 101 & 2.60 & 3.03 & 0.18 & 250 & 0.73 \\
\hline Betula alba & 97 & 6.34 & 13.2 & 8.67 & 634 & 35.2 \\
\hline Total & 100 & 5.88 & 12.8 & 19.25 & 1492 & 73.5 \\
\hline
\end{tabular}

*Legend: $A$ - average age of trees; $H$ - mean stand height; $D$ - mean stand diameter at breast height; $G$ - basal area; $N$ - number of trees per ha; $V$ - stem volume.

Table 2. Standard forest mensuration data of sample plots in the arctic ecotone

\begin{tabular}{|c|c|c|c|c|c|c|}
\hline Plot number & $\begin{array}{l}\text { Species composition, } \% \\
\text { by stem volume* }\end{array}$ & $A$, years & $H, \mathrm{~m}$ & $D, \mathrm{~cm}$ & $N$, trees ha ${ }^{-1}$ & $V, \mathrm{~m}^{3} \mathrm{ha}^{-1}$ \\
\hline \multicolumn{7}{|c|}{ Uplands, Larix vacciniosum } \\
\hline 1 & $100 \mathrm{~L}$ & 45 & 7.6 & 6.6 & 1740 & 24.2 \\
\hline 2 & 80L20B & 102 & 9.3 & 10.9 & 550 & 25.3 \\
\hline 3 & 50L30P20S & 100 & 9.5 & 11.9 & 677 & 38.0 \\
\hline 4 & 70L30B & 102 & 9.4 & 11.1 & 798 & 40.9 \\
\hline \multicolumn{7}{|c|}{ Floodplains, Hylocomiosum type } \\
\hline 5 & 70L20P10B & 25 & 7.0 & 4.8 & 6993 & 55.4 \\
\hline 6 & 90L10B & 27 & 6.9 & 5.1 & 5188 & 42.1 \\
\hline 7 & $100 \mathrm{~L}$ & 27 & 8.0 & 5.8 & 8555 & 111.0 \\
\hline 8 & 70L30B & 29 & 6.8 & 4.7 & 10740 & 77.9 \\
\hline 9 & $100 \mathrm{~L}$ & 45 & 15.2 & 15.0 & 1329 & 200.0 \\
\hline 10 & 70L30B & 46 & 11.0 & 7.1 & 7050 & 168.0 \\
\hline \multicolumn{7}{|c|}{ Floodplains, Ledosum type } \\
\hline 11 & 70L10P10S10B & 76 & 9.2 & 7.5 & 7167 & 164.0 \\
\hline 12 & 30L30P10S30B & 80 & 13.0 & 12.0 & 2100 & 177.0 \\
\hline 13 & 80L10P10B & 100 & 19.3 & 19.0 & 438 & 121.0 \\
\hline 14 & 70L10P20B & 119 & 16.3 & 14.7 & 1825 & 262.0 \\
\hline 15 & 60L30P10S & 230 & 16.2 & 17.6 & 1195 & 249.0 \\
\hline 16 & 80L10S10B & 260 & 23.7 & 31.3 & 944 & 446.0 \\
\hline 17 & $50 \mathrm{~L} 40 \mathrm{P} 10 \mathrm{~S}$ & 350 & 21.0 & 24.0 & 484 & 218.0 \\
\hline
\end{tabular}

*Species legend: L - larch (Larix sp.); P -Siberian stone pine (Pinus sibirica); S - spruce (Picea obovata); B birch (Betula tortuosa). The definition of variables as in Table 1.

As the trees in the study areas grow under extreme conditions, they develop extreme stem and crown forms that need special treatment when estimating biomass. Therefore, altogether 133 sample trees were selected from the sample plots for destructive measurements: 25 trees (19 spruce, four birch and two Siberian pine) in the alpine ecotone and 108 trees in the arctic ecotone (28 at higher elevations and 80 in the floodplains). The methods used were slightly different for biomass estimation on alpine and arctic ecotones. 
Stem biomass was determined by first measuring stem diameter inside and outside bark at different heights at distances of 1-2 $\mathrm{m}$ along the stems. From this data, volume was calculated. Then, volume was converted to weight using basic density that was calculated for each discs that was cut from the trees at the height of the diameter measurements. In order to measure the biomass of the crown, it was divided into three equal parts, each of them was entirely weighed, and then the proportion of the foliage was determined either by direct picking off the leaves (for small trees) or by cutting off portions of green shoots with foliage having the volume approximately $700 \mathrm{~g}$ by pruning shears (for larger trees). The variation of the foliage proportion in the mass of the woody greens in Scots pine forests was found to be only $2 \%$ to $5 \%$ (Usoltsev, 1988) by measuring sample branches from the crown.

As opposed to spruce trees that have needles on the outer part of the crown only, larch trees have needles also on the inner part of their crown as well as on the upper part of their stem. Therefore, in addition to estimating the needle mass on the outer part of larch crown we picked the needles both from the crown inner part of sample trees and from their stems. The foliage proportion in the mass of the woody greens was $50 \pm 3 \%(\mathrm{CV}=6 \%)$.

To convert fresh mass of foliage and branches to dry biomass, we took three samples of foliage and three discs from each sample tree, regardless of their position in the crown: one from large, one from middle-sized and one from small branches. They were weighed, oven-dried at $100^{\circ} \mathrm{C}$, and after the second weighing that proved that weight stabilized, values of dry matter content were calculated. Total tree foliage and branch dry biomass were calculated using these sample data. Forest biomass was calculated using the allometric method (Satoo, 1962), i.e., an allometric equation is developed for each biomass fraction based on the breast height diameter of the trees sampled to measure these biomass fractions, and then these equations are used for all trees with breast height at the sample plot for upscaling. Finally, tree biomass data were converted to carbon data using a conversion factor of 0.50 for woody parts of the tree and 0.45 for needle foliage (Kobak, 1988).

Different allometric equations were used in the two ecotones, i.e., equation (1) for the spruce sample trees in the alpine ecotone, and equation (2) for the larch sample trees in the arctic ecotone:

$$
\begin{gathered}
\ln C i=\mathrm{a}_{0}+\mathrm{a}_{1} \ln d b h+\mathrm{a}_{3}(\ln d b h)(\ln h) \\
\ln C i=\mathrm{a}_{0}+\mathrm{a}_{1} \ln d b h+\mathrm{a}_{2} \ln h+\mathrm{a}_{3}(\ln d b h)(\ln h)
\end{gathered}
$$

where, $C_{i}$ is the amount of carbon in the $i$-th tree biomass fraction, $\mathrm{kg}$, separately for stems under bark, $C s$, stem bark, $C s b$, branches, $C b r$, needle, $C f$, and aboveground biomass, $C a ; d b h$ - diameter at breast height, $\mathrm{cm}$.

\section{Results and Discussion}

Statistics of dry matter measurements are given in Tables 3 and 4 for spruce and larch, respectively. The results of fitting data to Equation (1) and (2) for the two ecotones can be found in Tables 5 and 6, respectively.

\begin{tabular}{|c|c|c|c|c|}
\hline \multirow{2}{*}{ Biomass fractions } & \multicolumn{4}{|c|}{ Dry matter statistics* } \\
\hline & $M$ & $C V$ & Range & $n$ \\
\hline \multicolumn{5}{|c|}{ Picea obovata } \\
\hline Stem wood & 50.8 & 6.6 & $45 \div 58$ & 16 \\
\hline Stem bark & 40.4 & 10.1 & $34 \div 49$ & 19 \\
\hline Foliage & 39.3 & 10.2 & $31 \div 46$ & 19 \\
\hline Branches & 48.7 & 10.0 & $40 \div 59$ & 18 \\
\hline \multicolumn{5}{|c|}{ Betula alba } \\
\hline Stem wood & 65.4 & 6.2 & $62 \div 69$ & 4 \\
\hline Stem bark & 54.5 & 7.9 & $50 \div 59$ & 4 \\
\hline Foliage & 30.0 & 11.5 & $26 \div 34$ & 4 \\
\hline Branches & 60.9 & 3.2 & $60 \div 64$ & 4 \\
\hline \multicolumn{5}{|c|}{ Pinus sibirica } \\
\hline Stem wood & 45.5 & - & - & 1 \\
\hline Stem bark & 41.5 & - & - & 2 \\
\hline Foliage & 34.6 & - & - & 2 \\
\hline Branches & 43.0 & - & - & 2 \\
\hline
\end{tabular}

Table 3. Content of dry matter (\%) in biomass fractions of the trees in the alpine ecotone

* $M$ - average value; $\pm \sigma-$ mean deviation; $C V$ - variation coefficient, \%; $n$ - a number of measurements. 
Table 4. Dry matter statistics of Larix sibirica biomass in the arctic ecotone

\begin{tabular}{clcccc}
\hline \multirow{2}{*}{ Biomass statistic } & \multirow{2}{*}{ Biomass fraction } & \multicolumn{4}{c}{ Statistics } \\
\cline { 3 - 5 } & & $M$ & $C V$ & Range & $n$ \\
\hline \multirow{3}{*}{ Dry matter content, \% } & Stem above bark & 48.5 & 10.5 & $35-58$ & 27 \\
& Foliage & 25.4 & 16.3 & $18-36$ & 78 \\
& Branches & 50.4 & 8.2 & $42-59$ & 79 \\
\hline Basic density, $\mathrm{kg} / \mathrm{m}^{3}$ & Stem above bark & 46.2 & 3.8 & $41-49$ & 104 \\
\hline
\end{tabular}

Table 5. Regression statistics of Equation (1) for the spruce trees in the alpine ecotone. All variables are significant at the level $\mathrm{P}_{05}$. The equation is valid in the diameter range from 1.0 to $24.0 \mathrm{~cm}$ and the height range from 1.4 to 8.8 m

\begin{tabular}{|c|c|c|c|c|c|}
\hline \multirow{2}{*}{ biomass compartment } & \multicolumn{3}{|c|}{ Regression coefficients } & \multirow{2}{*}{$\mathrm{R}^{2}$} & \multirow{2}{*}{ SE } \\
\hline & $\mathrm{a}_{0}$ & $a_{1}$ & $a_{3}$ & & \\
\hline Cs & -1.3890 & 0.6405 & 0.4598 & 0.967 & 0.29 \\
\hline $\mathrm{Cbr}$ & -1.8464 & 0.5628 & 0.4619 & 0.934 & 0.40 \\
\hline$C f$ & -2.2393 & 0.6864 & 0.3533 & 0.936 & 0.36 \\
\hline $\mathrm{Ca}$ & -0.6296 & 0.6069 & 0.4552 & 0.973 & 0.26 \\
\hline
\end{tabular}

Table 6. Regression statistics of equation (2) for the larch trees in the arctic ecotone. All variables are significant at the level $\mathrm{P}_{05}$. The equation is valid in the diameter range from 2.0 to $38.0 \mathrm{~cm}$ and in tree height range from 2.9 to $24.9 \mathrm{~m}$

\begin{tabular}{|c|c|c|c|c|c|c|}
\hline \multirow{2}{*}{ biomass compartment } & \multicolumn{4}{|c|}{ Regression coefficients } & \multirow{2}{*}{$\mathrm{R}^{2}$} & \multirow{2}{*}{$\mathrm{SE}$} \\
\hline & $a_{0}$ & $a_{1}$ & $a_{2}$ & $a_{3}$ & & \\
\hline$C s$ & -3.7081 & 1.4629 & 0.7850 & 0.1436 & 0.995 & 0.11 \\
\hline $\mathrm{Cbr}$ & -2.2763 & 2.6169 & -2.2428 & 0.2843 & 0.932 & 0.40 \\
\hline$C f$ & -4.1470 & 2.5203 & -1.4266 & 0.0838 & 0.892 & 0.44 \\
\hline $\mathrm{Ca}$ & -2.9351 & 1.5490 & 0.3419 & 0.1829 & 0.994 & 0.12 \\
\hline
\end{tabular}

Table 7. Biomass carbon stocks of the basic forest forming species by altitudinal levels at the upper tree limit between 864 and $960 \mathrm{~m}$ above sea level in the alpine ecotone

\begin{tabular}{|c|c|c|c|c|c|c|c|}
\hline \multirow{2}{*}{ Tree species } & \multirow{2}{*}{$A$, years } & \multirow{2}{*}{$V, \mathrm{~m}^{3} \mathrm{ha}^{-1}$} & \multicolumn{5}{|c|}{ Carbon in forest biomass, $\mathrm{tCha}^{-1} *$} \\
\hline & & & $C s+C s b$ & $C s b$ & $\mathrm{Cbr}$ & $C f$ & $\mathrm{Ca}$ \\
\hline \multicolumn{8}{|c|}{ Plot 1: altitudinal level 1 (960 $m$ a.s.l.) } \\
\hline Picea obovata & 28 & 2.94 & 0.665 & 0.055 & 0.480 & 0.306 & 1.451 \\
\hline Pinus sibirica & 40 & 0.17 & 0.033 & 0.007 & 0.012 & 0.005 & 0.050 \\
\hline Total & 30 & 3.11 & 0.698 & 0.062 & 0.492 & 0.311 & 1.501 \\
\hline \multicolumn{8}{|c|}{ Plot 2: altitudinal level 2 (924 $m$ a.s.l.) } \\
\hline Picea obovata & 79 & 18.9 & 4.27 & 0.20 & 1.06 & 0.617 & 5.947 \\
\hline Abies sibirica & 102 & 2.02 & 0.40 & 0.020 & 0.100 & 0.059 & 0.559 \\
\hline Betula alba & 40 & 1.29 & 0.31 & 0.019 & 0.125 & 0.014 & 0.449 \\
\hline Total & 80 & 22.2 & 4.98 & 0.239 & 1.285 & 0.690 & 6.955 \\
\hline \multicolumn{8}{|c|}{ Plot 3: altitudinal level 3 (864 $m$ a.s.l.) } \\
\hline Picea obovata & 99 & 37.6 & 8.500 & 0.515 & 5.250 & 2.426 & 16.18 \\
\hline Abies sibirica & 101 & 0.73 & 0.145 & 0.009 & 0.090 & 0.041 & 0.276 \\
\hline Betula alba & 97 & 35.2 & 8.450 & 0.510 & 3.415 & 0.405 & 12.27 \\
\hline Total & 100 & 73.5 & 17.10 & 1.034 & 8.755 & 2.872 & 28.73 \\
\hline
\end{tabular}

*Legend: $C s, C s b, C b r, C f$ and $C a$ are for carbon stock of biomass of stems under bark, stem bark, branches, foliage, and aboveground part, respectively. 
The analysis of the forest mensuration data on the sample plots (Table 1) suggests that on the lower level (864 $\mathrm{m}$ a.s.1.) a mixed spruce-fir-birch forest was generated about 100 years ago. Approximately at the same time a higher position upslope (at the middle level of $924 \mathrm{~m}$ a.s.1.) was occupied by Abies sibirica trees. 20 years later spruce trees also reached middle altitudinal levels. Another 40 years later the upper level $(960 \mathrm{~m}$ a.s.l.) was occupied by Pinus sibirica trees, and after yet another 12 years the same level was reached by Picea obovata trees. Because of the progressive shift of the upper tree limit the Picea forest, age declines from 100 years at the lower level to 28 years at the upper level. Thus, following specific temporal dynamics of the relevant environmental factors, different species were pioneers in moving upslope at different time periods.

Concerning the carbon stock of Picea aboveground biomass, we detected an 11-fold drop between altitudinal levels of 864 and $960 \mathrm{~m}$ a.s.l. The total drop for all species was 19-fold (Table 7).

Stem volume in the arctic sample plots (Table 2) shows a substantial, 5 to 9-fold drop in Larix when moving away from floodplain zone, as the action of heat sink alongside with sediment discharge (Mironov, Agafonov, 1992) occurs only on a relatively narrow strip of the floodplain.

Table 8. Biomass as measured in the sample plots in the arctic ecotone.

\begin{tabular}{|c|c|c|c|c|c|c|}
\hline \multirow{2}{*}{ Plot number } & \multirow{2}{*}{$\begin{array}{l}\text { Species composition,\% } \\
\text { by stem volume* }\end{array}$} & \multicolumn{5}{|c|}{ Organic carbon in forest biomass, $\mathrm{tCha}^{-1}$} \\
\hline & & $C s+C s b$ & $C s b$ & $\mathrm{Cbr}$ & $C f$ & $\mathrm{Ca}$ \\
\hline \multicolumn{7}{|c|}{ Uplands, Larix vacciniosum } \\
\hline 1 & $100 \mathrm{~L}$ & 5.7 & 0.96 & 1.28 & 0.33 & 7.31 \\
\hline 2 & 80L20B & 5.6 & 1.54 & 0.67 & 0.15 & 6.42 \\
\hline 3 & 50L30P20S & 8.3 & 2.42 & 1.41 & 0.48 & 10.2 \\
\hline 4 & 70L30B & 9.4 & 2.06 & 2.03 & 0.40 & 11.8 \\
\hline \multicolumn{7}{|c|}{ Floodplains, Hylocomiosum type } \\
\hline 5 & $70 \mathrm{~L} 20 \mathrm{P} 10 \mathrm{~B}$ & 12.9 & 2.39 & 2.08 & 0.48 & 15.5 \\
\hline 6 & 90L10B & 9.9 & 1.78 & 1.71 & 0.58 & 12.2 \\
\hline 7 & $100 \mathrm{~L}$ & 26.5 & 3.93 & 3.35 & 1.09 & 30.9 \\
\hline 8 & 70L30B & 18.2 & 3.46 & 2.59 & 0.90 & 21.7 \\
\hline 9 & $100 \mathrm{~L}$ & 48.6 & 6.20 & 4.54 & 0.81 & 53.9 \\
\hline 10 & 70L30B & 38.8 & 7.75 & 2.47 & 0.90 & 42.2 \\
\hline \multicolumn{7}{|c|}{ Floodplains, Ledosum type } \\
\hline 11 & 70L10P10S10B & 37.3 & 8.65 & 4.14 & 0.81 & 42.3 \\
\hline 12 & 30L30P10S30B & 41.0 & 8.20 & 4.14 & 0.91 & 46.0 \\
\hline 13 & 80L10P10B & 29.6 & 4.48 & 3.03 & 0.54 & 33.2 \\
\hline 14 & 70L10P20B & 60.0 & 12.70 & 4.65 & 1.19 & 65.8 \\
\hline 15 & 60L30P10S & 55.8 & 13.80 & 2.43 & 0.72 & 59.0 \\
\hline 16 & 80L10S10B & 103.9 & 19.9 & 7.05 & 1.27 & 112.2 \\
\hline 17 & 50L40P10S & 53.1 & 7.75 & 4.78 & 0.58 & 58.5 \\
\hline
\end{tabular}

*Species legend: $\mathrm{L}$ - larch (Larix sp.); P -Siberian stone pine (Pinus sibirica); $\mathrm{S}$ - spruce (Picea obovata); B birch (Betula tortuosa). The definition of variables as in Table 1 .

The biological productivity indices of larch forests are characterized by a similar contrasts. At the age of 45 years and with similar stand densities (1300 to 1700 trees per ha), the carbon stock of the Larix aboveground biomass and needle biomass in floodplains were correspondingly 7.0 and 2.6 times higher than in uplands. In 100-year forests that difference is 5 and 2-fold, respectively (Table 8).

The comparison of the average biomass carbon stock of Larix sibirica in the floodplains of the Pur River with similar indices of L. gmelinii on Eastern Siberia at the same latitudes (Pozdnyakov, 1975; Mitrofanov, 1984; Shepashenko et al., 2001) shows an almost 5-fold excess of the first over the second (Table 9). The reason for that may be higher climate continentality or other related factor(s) (for example, the amount of precipitations or the amount of summer temperatures) in Eastern Siberia as compared to Northern Trans-Urals area by the Pur River. On the other hand, the average biomass carbon stock of $L$. sibirica (the lower Pur River, Northern Trans-Urals), $L$. gmelinii (Putorana Plateau, Middle Siberia) and L. cajanderi (the Yana River basin, Eastern Siberia) did not differ significantly and were correspondingly 9.5, 12.2 and $14.6 \mathrm{t} \mathrm{Cha}^{-1}$ (Table 9). Permafrost seems to be the common factor that limits larch growth on all those sites. 
Table 9. Aboveground biomass carbon stocks of larch forests in Middle and Eastern Siberia according to different studies

\begin{tabular}{|c|c|c|c|c|c|c|c|c|c|}
\hline \multirow[t]{2}{*}{ Plot No } & \multirow[t]{2}{*}{ Forest type } & \multirow{2}{*}{$\begin{array}{l}\text { Site } \\
\text { index }\end{array}$} & \multirow{2}{*}{$\begin{array}{c}\mathrm{A}, \\
\text { years }\end{array}$} & \multicolumn{5}{|c|}{ Carbon stock, $\mathrm{t} \mathrm{ha}^{-1}$} & \multirow{2}{*}{ Reference } \\
\hline & & & & Stems, total & Stem bark & Branches & Foliage & Total & \\
\hline \multicolumn{10}{|c|}{ Middle Siberia, Taimyr Peninsula, natural boundary Ary-Mas. $72^{0} 28^{\prime} \mathrm{N}, 101^{0} \mathrm{E}$ - Tundra, Larix gmelinii } \\
\hline 1 & Ledosum & $\mathrm{V} c$ & 142 & 3.44 & - & 1.36 & 0.22 & 5.02 & \multirow{5}{*}{ Knorre, 1977} \\
\hline 2 & Alnosum & $\mathrm{V} c$ & 142 & 2.07 & - & 1.00 & 0.09 & 3.16 & \\
\hline 3 & Caricosum & $\mathrm{V} c$ & 142 & 1.62 & - & 1.25 & 0.11 & 2.98 & \\
\hline 4 & Caricosum & $\mathrm{V} c$ & 142 & 0.15 & - & 0.21 & 0.03 & 0.39 & \\
\hline 5 & Caricosum & $\mathrm{V} c$ & 142 & 0.15 & - & 0.09 & 0.013 & 0.25 & \\
\hline \multicolumn{10}{|c|}{ Middle Siberia, Putorana Plateau. $70^{\circ} \mathrm{N}, 90^{\circ} \mathrm{E}$ - Forest-tundra, Larix gmelinii } \\
\hline 1 & Alnosum & $\mathrm{V}$ & 155 & 25.6 & - & 1.53 & 0.55 & 27.7 & Deyeva, \\
\hline 2 & Vacciniosum & $\mathrm{V} c$ & 155 & 1.51 & - & 0.20 & 0.045 & 1.75 & 1985,1987 \\
\hline 3 & Fruticosum & V & 150 & 6.60 & - & 2.75 & 0.23 & 9.58 & \multirow{6}{*}{ Pautova, 1976} \\
\hline 4 & Alnosum & V & 150 & 7.65 & - & 3.10 & 0.22 & 11.0 & \\
\hline 5 & Alnosum & V & 150 & 7.95 & - & 3.25 & 0.27 & 11.5 & \\
\hline 6 & Ledosum & V & 150 & 12.4 & - & 3.90 & 0.31 & 16.6 & \\
\hline 7 & Alnosum & $\mathrm{V}$ & 150 & 14.4 & - & 3.30 & 0.36 & 18.1 & \\
\hline 8 & Fruticosum & $\mathrm{V} c$ & 150 & 1.10 & - & 0.50 & 0.07 & 1.67 & \\
\hline
\end{tabular}

Eastern Siberia, Jakutiya, Zhigansk, Verkhoyansk. $67^{0} \mathrm{~N}, 123^{0} \mathrm{E}$ - Forest-tundra, uplands, Larix cajanderi

\begin{tabular}{llcccccccc}
\hline 1 & Ledosum & $\mathrm{V} b$ & 300 & 14.9 & 2.85 & 1.90 & 0.27 & 17.1 & Pozdnyakov, 1975 \\
2 & Ledosum & $\mathrm{V} a$ & 190 & 18.9 & 3.65 & 1.00 & 0.50 & 20.4 & Mitrofanov, 1984 \\
3 & Fruticosum & $\mathrm{V} a$ & 85 & 5.1 & 1.00 & 0.60 & 0.27 & 5.97 & \\
4 & Ledosum & $\mathrm{V} b$ & 350 & 15.7 & 2.45 & 1.35 & 0.31 & 17.4 & 16.7 \\
5 & Fruticosum & $\mathrm{V} a$ & 150 & 15.5 & 2.80 & 1.05 & 0.18 & 26.2 & \\
6 & Vacciniosum & $\mathrm{V}$ & 170 & 24.7 & 4.10 & 1.10 & 0.36 & \\
\hline
\end{tabular}

Eastern Siberia, Jakutiya, Zhigansk, Verkhoyansk. $67^{0} \mathrm{~N}, 123^{0} \mathrm{E}$ - Forest-tundra, valley, Larix cajanderi

\begin{tabular}{|c|c|c|c|c|c|c|c|c|c|}
\hline 1 & Uliginosum & IV & 60 & 21.5 & 4.15 & 3.65 & 0.54 & 25.7 & \multirow{7}{*}{ Mitrofanov, 1984} \\
\hline 2 & Vacciniosum & IV & 255 & 21.9 & 3.35 & 1.15 & 0.50 & 23.6 & \\
\hline 3 & Empetrosum-Ar & $\mathrm{V}$ & 90 & 3.05 & 0.60 & 0.45 & 0.23 & 3.73 & \\
\hline & ctoustaphylos & & & & & & & & \\
\hline 4 & Fruticosum & IV & 32 & 7.45 & 1.65 & 1.05 & 0.58 & 9.08 & \\
\hline 5 & $\begin{array}{l}\text { Empetrosum-Va } \\
\text { cciniosum }\end{array}$ & $\mathrm{V}$ & 44 & 14.6 & 3.25 & 0.55 & 0.36 & 15.5 & \\
\hline 6 & Vacciniosum & $\mathrm{V} a$ & 200 & 12.9 & 2.50 & 1.75 & 0.72 & 15.4 & \\
\hline \multicolumn{10}{|c|}{ Eastern Siberia, Jakutiya, Djanky River mouth. $67^{0} \mathrm{~N}, 133^{0} \mathrm{E}$ - Forest-tundra, uplands, Larix cajanderi } \\
\hline 1 & Sphagnosum & $\mathrm{V} c$ & 113 & 6.27 & 1.25 & 0.79 & 0.19 & 7.25 & \multirow{3}{*}{$\begin{array}{c}\text { Shepashenko et } \\
\text { al., } 2001\end{array}$} \\
\hline 2 & Sphagnosum & $\mathrm{V} b$ & 124 & 14.4 & 2.84 & 1.92 & 0.45 & 16.8 & \\
\hline 3 & Sphagnosum & $\mathrm{V} c$ & 115 & 3.38 & 0.68 & 0.48 & 0.12 & 3.98 & \\
\hline \multicolumn{10}{|c|}{ Forest-tundra, floodplains, Larix cajanderi } \\
\hline 1 & Vacciniosum & $\mathrm{V} a$ & 125 & 20.0 & 3.86 & 6.41 & 0.66 & 27.1 & \\
\hline 2 & Uliginosum & $\mathrm{V} b$ & 127 & 8.58 & 1.73 & 1.08 & 0.27 & 9.93 & \\
\hline 3 & Caricosum & $\mathrm{V} c$ & 92 & 1.62 & 0.34 & 0.13 & 0.04 & 1.79 & \\
\hline
\end{tabular}


The average biomass of larch forests in upland habitats on the lower Pur River exceeds almost 4-fold the corresponding value of larch in the natural boundary Ary-Mas on the Taimyr Peninsula $\left(72^{\circ} 30^{\prime} \mathrm{N}\right)$, which is the Northern-most habitat of L. gmelinii not only in central Siberia, but also on the whole planet (Knorre, 1977). This may be explained by different latitudes, i.e. by a lower amount of summer temperatures on Taimyr as compared to the lower Pur River.

\section{Conclusion}

Thus, carbon stocks in the forests of two treeline ecotones of the Ural region are estimated for the first time. The first is an alpine ecotone that is represented by an altitudinal gradient of the spruce-dominated forests on the Western slope of the Tylaiskii Kamen Mountain $\left(59^{\circ} 30^{\prime} \mathrm{N}, 59^{\circ} 00^{\prime} \mathrm{E}\right)$, at the alpine timber line that has risen from 864 to $960 \mathrm{~m}$ above sea level in the course of the last 100 years. The second is an arctic ecotone in larch-dominated forests at the lower course of the Pur River $\left(67^{0} \mathrm{~N}, 78^{0} \mathrm{E}\right)$, at the transition zone between closed floodplain forests and open or island-like communities of upland forests on tundra permafrost. There are large differences in the carbon of the aboveground biomass of both ecotones across environmental gradients. In the alpine treeline ecotone, a 19-fold drop of the carbon stocks was detected between the lower and higher altitudinal levels. In the arctic ecotone the aboveground biomass carbon stock of forests of similar densities (1300 to 1700 trees per ha) was 7 times as much in the river flood bed, and 5 times as much in mature, dense forests as the low density forests at higher elevations.

Our studies show that relatively small differences in climatic conditions in the treeline zones can significantly affect biomass carbon stocks. As a logical extension, this translates to significant differences in biomass carbon sink. In a similar fashion, the biomass carbon sink can significantly change in a changing climate in the treeline zones. Considering the large area of forests under such conditions, this suggests that if climate changes will take place as projected, the forest carbon sink may considerably increase which might provide a significant natural mitigation of climate change. However, further studies will be needed to estimate the magnitude of this mitigation potential of the arctic forests.

\section{References}

Andreyev, V. N. (1938). Survey the tundra reindeer pastures using aircraft. Works of the Institute of the Polar agriculture, animal husbandry, hunting management. Ser. "Reindeer Husbandry" (Issue 1. pp. 7-32) (in Russian).

Bugmann, H., \& Pfister, C. (2000). Impacts of interannual climate variability on past and future forest composition. Reg. Environ. Change, 1, 112-125. http://dx.doi.org/10.1007/s101130000015

Buks, I. I. (1966). Larch open forests in the North between the Lena and the Olenek Rivers. Bulletin MOIP. Otd. Biol., LXXI(4), 71-74 (in Russian).

Camarero, J. J., Gutierrez, E., \& Fortin, M. J. (2000). Spatial pattern of subalpine forest-alpine grassland ecotones in the Spanish Central Pyrenees. Forest Ecology and Management, 134, 1-16. http://dx.doi.org/10.1016/ S0378-1127(99)00241-8

Deyeva, N. M. (1985). Biomass amount in forest communities of the north-western part of Putorana Plateau. Rus. Botanical Journal, 70, 54-58 (in Russian).

Deyeva, N. M. (1987). Structure of vegetation mass in phytocoenoses forests of the north-western part of Putorana Plateau. Rus. Botanical Journal, 72, 505-511 (in Russian).

Doyev, S. K. (1973). On spruce forest productivity in Southern Primorye according to habitat altitude. Lesnaya Taksatsiya i Lesoustroistvo. Krasnoyarsk, Siberian Technological Institute, 2, 36-41(in Russian).

Famelis, T. V. (1977). Using ecological series method to reveal patterns of altitudinal distribution of plant communities. Geobotany, ecology and plant morphology in the Urals. Misc. Sverdlovsk Branch of the All-Union Botanical Society. Sverdlovsk, 7, $22-27$ (in Russian).

Fomin, V. V. (2009). Climate driven and anthropogenic spatio-temporal dynamics of tree vegetation in the second half of the XXth century (p. 149). Yekaterinburg: Ural Branch of Russian Academy of Sciences (in Russian).

Gorchakovskii, P. L., \& Shiyatov, S. G. (1985). Phyto-indication of environmental conditions and natural processes in the Highlands (p.208). Moskow: Nauka Publishing (in Russian).

Gorodkov, B. N. (1916). Experiences of dividing the West-Siberian lowland on the botanical-geographical areas. Ezhegodnik Tobol'skogo gubernskogo muzeya. Tobol'sk, 27, 1-56 (in Russian). 
Grafius, D. R. (2012). Distribution and biomass dynamics of the alpine treeline ecotone across the western United States (p. 237). University of Iowa. Dissertation. Retrieved from http://ir.uiowa.edu/etd/2880

Grigoriev, A. A., Moiseyev, P. A., \& Nagimov, Z. Y. (2012). The formation of forests in the highlands of the Subpolar Urals in today's climate change (p. 170). Ekaterinburg: Ural State Forest Engineering University (in Russian).

Hacquet, B. H. (1780). Mineralogisch-botanische Lustreise von dem Berge Terglou in Krain zu dem Berge Glockner in Tirol, im Jahre 1779. Schriften der Berlinischen Gesellschaft naturforschender Freunde, 1, 119-201.

Hessl, A. E., \& Baker, W. L. (1997). Spruce-fir growth form changes on the forest-tundra ecotone of Rocky Mountain National Park, Colorado, USA. Ecography, 20, 356-367. http://dx.doi.org/10.1111/j.1600-0587. 1997.tb00380.x

Holtmeier, F. K. (2003). Mountain Timberlines. Ecology, Patchiness, and Dynamics (p. 369). Dordrecht, Boston, London: Kluwer Academic Publishers. http://dx.doi.org/10.1007/978-94-015-1254-1

IPCC. (2013). Climate Change 2013: The Physical Science Basis. Contribution of Working Group I to the Fifth Assessment Report of the Intergovernmental Panel on Climate Change (T. F. Stocker et al. (Eds.), p. 1535). Cambridge and New York: Cambridge University Press.

Juntunen, V., \& Neuvonen, S. (2006). Natural regeneration of Scots pine and Norway spruce close to the timberline in northern Finland. Silva Fennica, 40(3), 443-458.

Kapralov, D. S., Shiyatov, S. G., Moiseev, P. A., \& Fomin, V. V. (2006). Changes in the composition, structure and altitudinal distribution of low forests at the upper limit of their growth in the Northern Ural Mountains. Russian Journal of Ecology, 37(6), 367-372. http://dx.doi.org/10.1134/S1067413606060014

Karelin, D. V., Zamolodchikov, D. G., \& Gilmanov T. G. (1995). Reserves and production of carbon in phytomass of tundra and forest-tundra ecosystems in Russia. Lesovedenie, 5, 29 - 36 (in Russian).

Kharuk, V. I., Naurzbayev, M. M., Fedotova, E. V., \& Mezentsev, A. G. (1998). Reaction of wood vegetation on climate change on transition belt forest-tundra. Air-space methods and geoinformation systems in forestry and forest management. Moscow. Scientific center of natural resource studying (in Russian).

Kirdyanov, A. V., Knorre, A. A., Rigling, A., Fedotova, E. V., \& Naurzbaev, M. M. (2006). Vegetation and above-ground phytomass changes along an altitudinal transect at the tree-line ecotone of the Putorana Mountains (Siberia). Climate changes and their impact on boreal and temperate forests: Abstr. Int. Confer. (p. 43). Yekaterinburg: Ural State Forest Engineering University.

Knorre, A. V. (1977). Larch aboveground biomass in basic communities of the Ary-Mas forest. Transactions of State Reserve "Stolby". Krasnoyarsk, 11, 91-100 (in Russian).

Kobak, K. I. (1988). Biotic components of carbon cycle (p. 248). Leningrad. Gidrometeoizdat (in Russian).

Körner, C. (1999). Alpine Plant Life (p. 343). Berlin, Heidelberg: Springer-Verlag. http://dx.doi.org/10.1007/978 -3-642-98018-3

Krylova, I. L., \& Leskov, N. D. (1959). Relationship between spruce growth and altitude in the Northern Urals. Misc. Forest Manage. Sverdlovsk, 5, 91-96 (in Russian).

Kullman, L. (1990). Dynamics of altitudinal tree-limits in Sweden: a review. Norsk. Geogr. Tidsskr., 44, 103-116. http://dx.doi.org/10.1080/00291959008552248

Madgwick, H. A. I. (1982). Estimating the above-ground weight of forest plots using the basal area ratio method. N. Z. J. Forest Sci., 11(3), 278-286.

Matveev, A. V., \& Semerikov, L. F. (1993). Ecological characteristics of the Siberian larch (Larix sibirica Ldb.) on the polar limit of forests. A species and productivity on its habitat: materials of VI meeting. Sankt-Peterburg (pp. 319 - 320) (in Russian).

Medvedev, P. M. (1952). On forest limits and reasons of the lack of forests in Asian tundras. Izvestiya Vsesoyuznogo Geograficheskogo Obshchestva, 3, 229-237 (in Russian).

Mironov, B. A., \& Agafonov, L. I. (1992). Forest vegetation of the floodlands on the lower Ob' River. Floodlands nature of the lower Ob' River: terrestrial ecosystems. Yekaterinburg. Ural Branch of Russian Academy of Sciences (pp. 92-116) (in Russian). 
Mitrofanov, D. P. (1984). Evaluating productivity of Siberian northern taiga forests. Productivity of forest phytocoenoses. Krasnoyarsk (pp. 95-102). Sukachev Forest Institute (in Russian).

Moiseev, P. A., \& Shiyatov, S. G. (2003). Vegetation dynamics at the treeline ecotone in the Ural highlands, Russia (pp. 423-435). Ecological Studies, 167. Springer Berlin Heidelberg.

Norin, B. N. (1961). What is forest-tundra? Botanicheskii Zhurnal, 46(1), 21-38 (in Russian).

Pautova, V. N. (1976). Aboveground plant mass and transpiration of certain communities in forest-tundra zone. Transactions of Limnological Inst., 22(42), 92-128 (in Russian).

Pozdnyakov, L. K. (1963). Hydrologic and climatic regime of larch forests in Central Yakutia (p. 146). Moscow. Publishing of the Academy of Sciences of the USSR (in Russian).

Pozdnyakov, L. K. (1975). Productivity of Siberian Forests. Biospheric resources: Synthesis of Soviet studies for the International Biological Programme. Leningrad: Nauka publishing, 1, 43-55 (in Russian).

Pryazhnikov, A. A., \& Utkin, A. I. (1998). Closed and open larch forests of Russian Sub-Arctic. Ecology of taiga forests (pp. 93-95). Misc. Int. Conf. Syktyvkar. (in Russian).

Satoo, T. (1962). Notes on Kittredge's method of estimation of amount of leaves of forest stand. J. Jap. Forest Soc. 44(2), 267-272.

Shchepashchenko, D. G., Shchepashchenko, M. V., \& Pakai, O. D. (2001). Biological productivity of forests in North-Eastern Yakutia depending on soil conditions. Lesnoi Vestnik (MGUL), 1, 165-169 (in Russian).

Shiyatov S. G., Terent'ev, M. M., Fomin, V. V., \& Zimmermann, N. E. (2007). Altitudinal and horizontal shifts of the upper boundaries of open and closed forests in the Polar Urals in the 20th century. Russian Journal of Ecology, 38(4), 223-227. http://dx.doi.org/10.1134/S1067413607040017

Shiyatov, S. G. (1985). Concept of the upper limit of forests. Vegetable world of the Urals and its anthropogenic change. Sverdlovsk (pp. 32-58). Ural Scientific Center of the Academy of Sciences of the USSR. (in Russian).

Shiyatov, S. G. (2003). Rates of change in the upper treeline ecotone in Polar Ural Mountains. PAGES News, 11(1), $8-10$.

Shiyatov, S. G., Terent'ev, M. M., \& Fomin, V. V. (2005). Spatio-temporal dynamics of forest-tundra communities in the Polar Urals. Russian Journal of Ecology, 36(2), 69-75. http://dx.doi.org/10.1007/s11184 -005-0051-9

Sochava, V. B., Isachenko T. I., \& Lukicheva A. N. (1953). Common features of the geographical distribution of forest vegetation on West Siberian lowland. Izvestiya vsesoyuznogo ograficheskogo obshchestva, 85(2), 125-138 (in Russian).

Stevens, G. C., \& Fox, J. (1991). The causes of treeline. Annu. Rev. Ecol. Syst., 22, 177-191. http://dx.doi.org/10.1 146/annurev.es.22.110191.001141

Tikhomirov, B. A. (1962). Tundra treelessness, phenomenon reasons and solutions (p. 89). Moscow, Leningrad. Academy of Sciences of the USSR (in Russian).

Usoltsev, V. A. (1988). Principles and methods of compiling stand bioproductivity tables. Soviet Forest Sciences, 2, 23-32 (Allerton Press Inc.).

Usoltsev, V. A. (2013). Forest biomass and primary production database for Eurasia. CD-version (2nd ed., enlarged and re-harmonized). Yekaterinburg: Ural State Forest Engineering University. Retrieved from http://elar.usfeu.ru/handle/123456789/3059

Walter, H., \& Box, E. (1976). Global classification of natural terrestrial ecosystems. Vegetation, 32(2), 75-81. http://dx.doi.org/10.1007/BF02111901

\section{Copyrights}

Copyright for this article is retained by the author(s), with first publication rights granted to the journal.

This is an open-access article distributed under the terms and conditions of the Creative Commons Attribution license (http://creativecommons.org/licenses/by/3.0/). 